\title{
POLR3-related leukodystrophy: How do mutations affecting RNA polymerase III subunits cause hypomyelination?
}

\author{
Benoit Coulombe ${ }^{1,2^{*}} \quad$ Alexa Derksen ${ }^{1,3,4}$ Roberta La Piana ${ }^{5,6}$ Bernard Brais ${ }^{5,7}$ Marie-Soleil Gauthier ${ }^{1}$ \\ Geneviève Bernard 3,4,7-9 \\ ${ }^{1}$ Department of Translational Proteomics, Institut de Recherches Cliniques de Montréal, Montréal, QC, Canada \\ ${ }^{2}$ Department of Biochemistry and Molecular Medicine, Université de Montréal, Montréal, QC, Canada \\ ${ }^{3}$ Child Health and Human Development Program, Research Institute of the McGill University Health Centre, Montréal, QC, Canada \\ ${ }^{4}$ Department of Neurology and Neurosurgery, McGill University, Montréal, QC, Canada \\ ${ }^{5}$ Department of Neurology and Neurosurgery, Montreal Neurological Institute, McGill University, Montréal, QC, Canada \\ ${ }^{6}$ Department of Diagnostic Radiology, McGill University, Montréal, QC, Canada \\ ${ }^{7}$ Department of Human Genetics, McGill University, Montréal, QC, Canada \\ ${ }^{8}$ Department of Pediatrics, McGill University, Montréal, QC, Canada \\ ${ }^{9}$ Department of Specialized Medicine, Division of Medical Genetics, McGill University Health Center, Montréal, QC, Canada
}

\begin{abstract}
Hypomyelinating leukodystrophies are a group of genetic disorders characterized by insufficient myelin deposition during development. A subset of hypomyelinating leukodystrophies, named RNA polymerase III (Pol III or POLR3)-related leukodystrophy or 4H (Hypomyelination, Hypodontia and Hypogonadotropic Hypogonadism) leukodystrophy, was found to be caused by biallelic variants in genes encoding subunits of the enzyme Pol III, including POLR3A, POLR3B, POLR3K, and POLR1C. Pol III is one of the three nuclear RNA polymerases that synthesizes small non-coding RNAs, such as tRNAs, 5S RNA, and others, that are involved in the regulation of essential cellular processes, including transcription, translation and RNA maturation. Affinity purification coupled with mass spectrometry (AP-MS) revealed that a number of mutations causing POLR3-related leukodystrophy impair normal assembly or biogenesis of Pol III, often causing a retention of the unassembled subunits in the cytoplasm. Even though these proteomic studies have helped to understand the molecular defects associated with leukodystrophy, how these mutations cause hypomyelination has yet to be defined. In this review we propose two main hypotheses to explain how mutations affecting Pol III subunits can cause hypomyelination.
\end{abstract}

\section{Keywords}

leukodystrophy, RNA polymerase III, genetic disease, protein complex assembly, myelination

\section{Peer Review}

The peer reviewers who approve this article are:

1. Ali Reza Tavasoli, Myelin Disorders Clinic, Pediatric Neurology Division, Children's Medical Center, Pediatrics Center of Excellence, Tehran University of Medical Sciences, Tehran, Iran

Competing interests: No competing interests were disclosed.

2. Joshua L. Bonkowsky, Department of Pediatrics, University of Utah School of Medicine, Salt Lake City, UT, USA Competing interests: No competing interests were disclosed.

3. Marc Engelen, Department of Paediatric Neurology, Emma Children's Hospital, Amsterdam UMC, University of Amsterdam, the Netherlands

Competing interests: No competing interests were disclosed. 
*Corresponding author: Benoit Coulombe (benoit.coulombe@ircm.qc.ca)

Competing interests: The authors declare that they have no competing interests.

Grant information: This study was supported by grants from the Canadian Institutes of Health Research (CIHR, 201610PJT-377869, project grant 426534). BC is the recipient of the IRCM Bell-Bombardier Research Chair. AD is supported by the CIHR Canadian Graduates Scholarships Master's, the Fondation du Grand Defi Pierre Lavoie Master's Scholarship, and Heathy Brains for Healthy Lives Masters Fellowship. GB has received a Research Scholar Junior 1 award from the Fonds de Recherche du Québec - Santé (FRQS) (2012-2016) and the New Investigator Salary Award from the CIHR (2017-2022).

The funders had no role in study design, data collection and analysis, decision to publish, or preparation of the manuscript.

Copyright: (C) 2021 Coulombe B et al. This is an open access article distributed under the terms of the Creative Commons Attribution License, which permits unrestricted use, distribution, and reproductison in any medium, provided the original work is properly cited.

How to cite this article: Coulombe B, Derksen A, La Piana R, Brais B, Gauthier MS and Bernard G. POLR3-related leukodystrophy: How do mutations affecting RNA polymerase III subunits cause hypomyelination? Faculty Reviews 2021 10:(12) https://doi.org/10.12703/r/10-12

Published: 05 Feb 2021, Faculty Reviews 10:(12) https://doi.org/10.12703/r/10-12 
Leukodystrophies are a heterogeneous group of genetically determined disorders characterized by abnormal white matter on brain imaging ${ }^{1,2}$. The white matter's major component is represented by myelin that contains mainly lipids and proteins in a ratio of 2.5 to $3: 1$. Given myelin's central role in white matter composition, leukodystrophies are classified as hypomyelinating and non-hypomyelinating on the basis of magnetic resonance imaging characteristics ${ }^{2}$, depending on whether the principal problem appears to be a lack of myelin deposition during development or altered myelin homeostasis. Historically, hypomyelinating leukodystrophies have been considered disorders caused by mutations in genes encoding myelin protein constituents such as proteolipid protein and myelin basic protein. In the last decade, it has become clear that mutations in genes encoding proteins important for transcription and translation also lead to hypomyelinating leukodystrophies. A subset of leukodystrophies named RNA polymerase III (Pol III)-related leukodystrophy or $4 \mathrm{H}$ (hypomyelination, hypodontia, and hypogonadotropic hypogonadism) leukodystrophy (MIM 607694, $614381)^{3}$ was found to be caused by biallelic pathogenic variants in genes encoding specific subunits of the enzyme Pol III, namely POLR3A, POLR3B, POLR3K, and POLR1C ${ }^{4-9}$. Figure 1 presents a structural model of Pol III, where these four (out of 17) subunits are highlighted, as is its DNA-binding active site. We suspect that mutations in genes encoding other Pol III subunits and other proteins important for transcription and translation are also leukodystrophy-causative, and next-generation sequencing, combined with functional experiments, is likely to identify them.

What was initially described as $4 \mathrm{H}$ syndrome ${ }^{10}$ was renamed POLR3-related leukodystrophy when the first two genes (POLR3A and POLR3B) were identified ${ }^{3-5}$. As the disease spectrum widens ${ }^{11-17}$, with hypomyelination not always present, and mutations in POLR3 genes being found to explain other previously described disorders, they are collectively increasingly referred to as POLR3-related disorders ${ }^{11-13,18-22}$. With this new definition, one other POLR3 gene, POLR3GL, was added to the list of genes with biallelic mutations causing disorders with overlapping manifestations but without a leukodystrophy ${ }^{23,24}$.

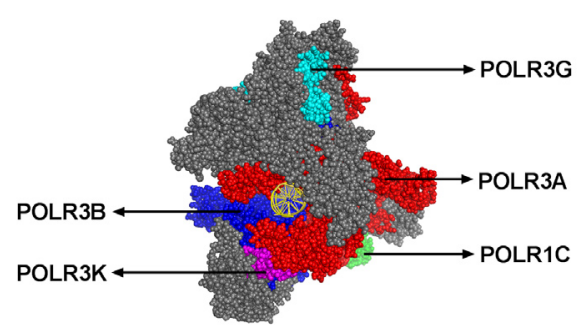

Figure 1. Side view of the cryogenic electron microscopy structure of the Saccharomyces cerevisiae RNA polymerase III open DNA complex (Protein Data Bank code: 6EU1) ${ }^{25}$. Template and non-template strands of DNA are shown in yellow (perpendicular to the screen). Human leukodystrophy-causative subunits POLR3A, POLR3B, POLR1C, and POLR3K are labelled. POLR3G, which is homologous to POLR3GL, is also indicated. All other subunits are in gray.
POLR3GL is an interesting Pol III subunit as it is homologous to POLR3G. They independently associate with the enzyme; POLR3G is found in undifferentiated cells and is shown to play a role in maintaining the pluripotent state, and POLR3GL is expressed ubiquitously ${ }^{26-29}$. As a consequence, two forms of Pol III can be purified and the specific role of each form in disease remains to be studied.

Pol III is one of the three nuclear RNA polymerases, the two others being Pol I and Pol II, and it synthesizes small non-coding RNAs - such as tRNAs, 5S RNA, 7SK RNA, and U6 RNA- that are involved in the regulation of essential cellular processes, including transcription, RNA processing, and translation ${ }^{30}$. Pol I synthesizes large rRNA while Pol II synthesizes all mRNA. Each polymerase possesses its own set of accessory factors that are required to transcribe their specific set of target genes. One would expect that affecting the activity of Pol III would have a general effect on gene expression and cell function rather than a specific effect on myelin formation or dental and pituitary development observed in patients. The pathophysiological link between mutations in genes encoding Pol III subunits and the involvement of such specific tissues remains unknown.

Affinity purification experiments coupled with mass spectrometry performed in HEK293 cells as a model system, in which wild-type and mutated subunits were compared, revealed that a number of mutations causing POLR3-related leukodystrophy impair proper assembly/biogenesis of Pol III, often causing a retention of the unassembled subunits in the cytoplasm as revealed by immunofluorescence and biochemical fractionation of cell lysates ${ }^{8,31}$. Even though these studies have helped elucidate the molecular defects associated with leukodystrophy, how these mutations cause hypomyelination has yet to be determined.

In our opinion, two main hypotheses can be favored at this stage to explain how mutations affecting RNA Pol III subunits can cause hypomyelination.

\section{Specific key POLR3 target(s) essential for myelin biogenesis}

Some authors have hypothesized that defects in Pol III function likely affect a key yet-unidentified component of the myelin biogenesis or maintenance apparatus. For instance, Choquet et al. found that the M852V mutation in POLR3A specifically downregulates expression of $B C 200$, a gene encoding a brain cytoplasmic regulatory $\mathrm{RNA}^{32}$. So far, a function for $\mathrm{BC} 200$ in regulating myelination has not been established conclusively.

\section{Globally reduced transcription and translation at a crucial neurodevelopmental milestone}

Another hypothesis is based on the evidence that the brain is particularly vulnerable during development. More specifically, oligodendrocytes (OLs) and their progenitors need a large amount of protein to be produced in order to mature, expand their processes, and myelinate the brain. Selective vulnerability of late OLs progenitors is a well-documented phenomenon 
in pediatric neuropathology ${ }^{33}$. Defects in Pol III transcription, by impairing the production of components of the translation machinery (tRNA and 5S rRNA), may have a deleterious effect on this particular process. This hypothesis is supported by the fact that other disorders where the pathophysiological mechanisms involve abnormal translation are also associated with hypomyelination ${ }^{34,35}$. Interestingly, mutations targeting genes for aminoacyl-tRNA synthetases (ARSs) (see, for example, Mendes et $a l .{ }^{34}$ and references therein) are also causative of a hypomyelinating leukodystrophy. ARSs play a central role in translation by charging the various tRNAs with their cognate amino acids.
It is also possible that a not-yet-understood biochemical pathway is involved in POLR3 function. Future studies should help to assess this idea.

Altogether, studies so far have characterized Pol III defects produced by mutations that are causative of various overlapping rare diseases. However, the mechanisms linking these to hypomyelination and other phenotypic characteristics (for example, hypodontia and hypogonadotropic hypogonadism) are still unknown at this stage. Clearly, additional studies are required to better elucidate the pathophysiology of POLR3-related disorders.
1. Schiffmann R, van der Knaap MS: The latest on leukodystrophies. Curr Opin Neurol. 2004; 17(2): 187-92.

PubMed Abstract | Publisher Full Text

2. Schiffmann R, van der Knaap MS: Invited article: An MRI-based approach to the diagnosis of white matter disorders. Neurology. 2009; 72(8): 750-9. PubMed Abstract | Publisher Full Text | Free Full Text

3. Bernard G, Vanderver A: POLR3-Related Leukodystrophy. In: M. P. Adam, H. H. Ardinger, R. A. Pagon, S. E. Wallace, L. J. H. Bean, K. Stephens and A. Amemiya, eds. GeneReviews(®) Seattle WA: @ 1993-2020, University of Washington, Seattle. GeneReviews is a registered trademark of the University of Washington, Seattle; 1993

Reference Source

4. Bernard G, Chouery E, Putorti ML, et al:: Mutations of POLR3A encoding a catalytic subunit of RNA polymerase Pol III cause a recessive hypomyelinating leukodystrophy. Am J Hum Genet. 2011; 89(3): 415-23. PubMed Abstract | Publisher Full Text | Free Full Text

5. Tétreault M, Choquet $\mathrm{K}$, Orcesi S, et al:: Recessive mutations in POLR3B, encoding the second largest subunit of Pol III, cause a rare hypomyelinating leukodystrophy. Am J Hum Genet. 2011; 89(5): 652-5. PubMed Abstract | Publisher Full Text | Free Full Text

6. Potic $\mathrm{A}, \mathrm{Brais} \mathrm{B}, \mathrm{Choquet} \mathrm{K}$, et al:: $\mathbf{4 H}$ syndrome with late-onset growth hormone deficiency caused by POLR3A mutations. Arch Neurol. 2012; 69(7): 920-3. PubMed Abstract | Publisher Full Text

7. Daoud H, Tétreault M, Gibson W, et al.: Mutations in POLR3A and POLR3B are a major cause of hypomyelinating leukodystrophies with or without dental abnormalities and/or hypogonadotropic hypogonadism. J Med Genet. 2013; 50(3): 194-7.

PubMed Abstract | Publisher Full Text

8. Thiffault I, Wolf NI, Forget D, et al:: Recessive mutations in POLR1C cause a leukodystrophy by impairing biogenesis of RNA polymerase III. Nat Commun. 2015; 6: 7623.

PubMed Abstract | Publisher Full Text | Free Full Text |

Faculty Opinions Recommendation

9. Dorboz I, Dumay-Odelot H, Boussaid K, et al.: Mutation in POLR3K causes hypomyelinating leukodystrophy and abnormal ribosomal RNA regulation. Neurol Genet. 2018; 4: e289.

PubMed Abstract | Publisher Full Text | Free Full Text |

Faculty Opinions Recommendation

10. Timmons M, Tsokos M, Asab MA, et al:: Peripheral and central hypomyelination with hypogonadotropic hypogonadism and hypodontia. Neurology. 2006; 67(11): 2066-9.

PubMed Abstract | Publisher Full Text | Free Full Text

11. Gauquelin $\mathrm{L}$, Tétreault $\mathrm{M}$, Thiffault I, et al:: POLR3A variants in hereditary spastic paraplegia and ataxia. Brain. 2018; 141: e1.

PubMed Abstract | Publisher Full Text | Free Full Text

12. La Piana R, Cayami FK, Tran LT, et al.: Diffuse hypomyelination is not obligate for POLR3-related disorders. Neurology. 2016; 86(17): 1622-6. PubMed Abstract | Publisher Full Text | Free Full Text

13. Al Yazidi G, Tran LT, Guerrero K, et al.: Dystonia in RNA Polymerase III-Related Leukodystrophy. Mov Disord Clin Pract. 2019; 6(2): 155-9.

PubMed Abstract | Publisher Full Text | Free Full Text
14

Ghoumid J, Petit F, Boute-Benejean O, et al.: Cerebellar hypoplasia with endosteal sclerosis is a POLR3-related disorder. Eur J Hum Genet. 2017; 25(8): 1011-4.

PubMed Abstract | Publisher Full Text | Free Full Text |

Faculty Opinions Recommendation

15. P Paolacci S, Li Y, Agolini E, et al:: Specific combinations of biallelic POLR3A variants cause Wiedemann-Rautenstrauch syndrome. J Med Genet. 2018; 55(12): 837-46.

PubMed Abstract | Publisher Full Text | Faculty Opinions Recommendation

16. Wambach JA, Wegner DJ, Patni N, et al:: Bi-allelic POLR3A Loss-of-Function Variants Cause Autosomal-Recessive Wiedemann-Rautenstrauch Syndrome. Am J Hum Genet. 2018; 103(6): 968-75.

PubMed Abstract | Publisher Full Text | Free Full Text

Faculty Opinions Recommendation

17. Minnerop M, Kurzwelly D, Wagner $\mathrm{H}$, et al:: Hypomorphic mutations in POLR3A are a frequent cause of sporadic and recessive spastic ataxia. Brain. 2017; 140(6): 1561-78.

PubMed Abstract | Publisher Full Text | Free Full Text |

Faculty Opinions Recommendation

18. DeGasperis SM, Bernard G, Wolf $\mathrm{NI}$, et al:: $4 \mathrm{H}$ leukodystrophy: Mild clinical phenotype and comorbidity with multiple sclerosis. Neurol Genet. 2020; 6(2): e409.

PubMed Abstract | Publisher Full Text | Free Full Text

19. Harting I, Al-Saady M, Krägeloh-Mann I, et al:: POLR3A variants with striatal involvement and extrapyramidal movement disorder. Neurogenetics. 2020; 21(2): 121-33.

PubMed Abstract | Publisher Full Text | Free Full Text

20. Jurkiewicz E, Dunin-Wąsowicz D, Gieruszczak-Białek D, et al.: Recessive Mutations in POLR3B Encoding RNA Polymerase III Subunit Causing Diffuse Hypomyelination in Patients with 4H Leukodystrophy with Polymicrogyria and Cataracts. Clin Neuroradiol. 2017; 27: 213-20.

PubMed Abstract | Publisher Full Text | Free Full Text

21. Wolf NI, Vanderver A, van Spaendonk RML, et al.: Clinical spectrum of $4 \mathbf{H}$ leukodystrophy caused by POLR3A and POLR3B mutations. Neurology. 2014; 83(21): 1898-905.

PubMed Abstract | Publisher Full Text | Free Full Text

22. Perrier S, Gauquelin L, Fallet-Bianco C, et al.: Expanding the phenotypic and molecular spectrum of RNA polymerase III-related leukodystrophy. Neurol Genet. 2020; 6(3): e425. PubMed Abstract | Publisher Full Text | Free Full Text

23. Terhal PA, Vlaar JM, Middelkamp S, et al.: Biallelic variants in POLR3GL cause endosteal hyperostosis and oligodontia. Eur J Hum Genet. 2020; 28(1): 31-9.

PubMed Abstract | Publisher Full Text | Free Full Text | Faculty Opinions Recommendation

24. Beauregard-Lacroix E, Salian S, Kim H, et al:: A variant of neonatal progeroid syndrome, or Wiedemann-Rautenstrauch syndrome, is associated with a nonsense variant in POLR3GL. Eur J Hum Genet. 2020; 28(4): 461-8. PubMed Abstract | Publisher Full Text | Free Full Text

25. Abascal-Palacios G, Ramsay EP, Beuron F, et al.: Structural basis of RNA 
polymerase III transcription initiation. Nature. 2018; 553(7688): 301-6. PubMed Abstract | Publisher Full Text | Faculty Opinions Recommendation

Lund RJ, Rahkonen N, Malonzo M, et al.: RNA Polymerase III Subunit POLR3G Regulates Specific Subsets of PolyA A $^{+}$and SmallRNA Transcriptomes and Splicing in Human Pluripotent Stem Cells. Stem Cell Reports. 2017; 8(5): 1442-54. PubMed Abstract | Publisher Full Text | Free Full Text | Faculty Opinions Recommendation

27. Renaud M, Praz V, Vieu E, et al:: Gene duplication and neofunctionalization: POLR3G and POLR3GL. Genome Res. 2014; 24(1): 37-51. PubMed Abstract | Publisher Full Text | Free Full Text | Faculty Opinions Recommendation

28. Wong RCB, Pollan S, Fong $\mathrm{H}$, et al:: A novel role for an RNA polymerase III subunit POLR3G in regulating pluripotency in human embryonic stem cells. Stem Cells. 2011; 29(10): 1517-27. PubMed Abstract | Publisher Full Text

29. Haurie V, Durrieu-Gaillard S, Dumay-Odelot $\mathrm{H}$, et al:: Two isoforms of human RNA polymerase III with specific functions in cell growth and transformation. Proc Natl Acad Sci U S A. 2010; 107(9): 4176-81.

PubMed Abstract | Publisher Full Text | Free Full Text | Faculty Opinions Recommendation

30. Dumay-Odelot H, Durrieu-Gaillard S, Da Silva D, et al:: Cell growth- and differentiation-dependent regulation of RNA polymerase III transcription. Cell
Cycle. 2010; 9(18): 3687-99.

PubMed Abstract | Publisher Full Text | Free Full Text

31. Choquet K, Pinard M, Yang S, et al.: The leukodystrophy mutation POLR3B R103H causes homozygote mouse embryonic lethality and impairs RNA polymerase III biogenesis. Mol Brain. 2019; 12(1): 59. PubMed Abstract | Publisher Full Text | Free Full Text

32. Choquet $\mathrm{K}$, Forget $\mathrm{D}$, Meloche $\mathrm{E}$, et al:: Leukodystrophy-associated POLR3A mutations down-regulate the RNA polymerase III transcript and important regulatory RNA BC200. J Biol Chem. 2019; 294(18): 7445-59. PubMed Abstract | Publisher Full Text | Free Full Text

33. Back SA: White matter injury in the preterm infant: Pathology and mechanisms. Acta Neuropathol. 2017; 134(3): 331-49. PubMed Abstract | Publisher Full Text | Free Full Text | Faculty Opinions Recommendation

34. Mendes MI, Gutierrez Salazar M, Guerrero K, et al:: Bi-allelic Mutations in EPRS, Encoding the Glutamyl-Prolyl-Aminoacyl-tRNA Synthetase, Cause a Hypomyelinating Leukodystrophy. Am J Hum Genet. 2018; 102(4): 676-84. PubMed Abstract | Publisher Full Text | Free Full Text

35. Taft RJ, Vanderver A, Leventer RJ, et al:: Mutations in DARS cause hypomyelination with brain stem and spinal cord involvement and leg spasticity. Am J Hum Genet. 2013; 92(5): 774-80. PubMed Abstract | Publisher Full Text | Free Full Text 